\title{
Autoimmunity complicating SARS-CoV-2 infection in selective IgA-deficiency
}

\author{
Steffen Pfeuffer, MD, Matthias Pawlowski, MD, PhD, Gunther S. Joos, Jens Minnerup, MD, \\ Sven G. Meuth, MD, PhD, Rainer Dziewas, MD, and Heinz Wiendl, MD
}

Neurol Neuroimmunol Neuroinflamm 2020;7:e881. doi:10.1212/NXI.0000000000000881

Coronavirus disease 2019 (COVID-19) caused by SARS-CoV-2 can result in severe disease and become critically challenging to hospitals via high demand for intensive care and mechanical ventilation.

Guillain-Barré syndrome (GBS) and its variants have been described as neurologic complications of COVID-19, and fatal cases were reported. ${ }^{1}$ The mechanisms by which COVID-19 predisposes to autoimmunity are unclear, and potential biomarkers or risk factors remain unknown.

\section{Case report}

A 35-year-old, healthy Caucasian woman initially presented with fever and coughing over 1 week (days 0-7, figure, A for timeline) at her family doctor and was subsequently tested positive for SARS-CoV-2 via PCR. The patient had experienced no other infections in previous weeks and had not received any vaccinations.

On day 8 , she developed severe diabetic ketoacidosis (DKA) as the first manifestation of type 1 diabetes (T1D; pH: 6.7; base excess: $-27 \mathrm{mmol} / \mathrm{L}$; blood glucose: $25.1 \mathrm{mmol} / \mathrm{L}, \mathrm{HbAlc}$ : 6.4\%), and antibodies against islet cell antigen 2 and glutamate decarboxylase (GAD65) were positive. There was no history of polyuria or polydipsia. She was admitted to intensive care unit and transiently recovered after fluid resuscitation and insulin treatment.

However, because of rapidly developing respiratory insufficiency, intubation became necessary on day 10. Chest $\mathrm{x}$-ray and CT scan showed signs suggestive of COVID-19.

During ICU treatment, the patient recovered from COVID-19, and nasopharyngeal swabs for SARS-CoV-2 were repeatedly negative (first on day 15 ). The patient was weaned from ventilatory support, and extubation was performed on day 17. Blood glucose levels remained well controlled throughout after IV insulin substitution.

However, restrictive lung disorder resulting from diaphragmatic paralysis rapidly evolved, and poor management of pharyngeal secretions forced reintubation within 24 hours. A rapidly progressive proximal tetraparesis and dysautonomia with tachycardia and absent heart rate variability were first noticed on day 19 and repeatedly let to self-limiting, symptomatic bradycardia on day 20.

MRI scans of the brain and cervical cord were unremarkable. CSF analysis showed albuminocytologic dissociation (CSF total protein: $1421 \mathrm{mg} / \mathrm{L}$, CSF cell count: $2 / \mu \mathrm{L}$, and CSF oligoclonal bands were negative). SARS-CoV-2 was not detectable in the CSF. Nerve conduction studies revealed widespread axonal damage as indicated by reduced compound motor action

\author{
Correspondence \\ Dr. Pfeuffer \\ steffen.pfeuffer@ukmuenster.de
}

\section{MORE ONLINE}

COVID-19 Resources

For the latest articles, invited commentaries, and blogs from physicians around the world

NPub.org/COVID19

From the Department of Neurology with Institute of Translational Neurology (S.P., M.P., J.M., S.G.M., R.D., H.W.) and Department for Anesthesiology, Intensive Care and Pain Medicine (G.S.J.), University Hospital Münster, Germany.

Go to Neurology.org/NN for full disclosures. Funding information is provided at the end of the article.

The Article Processing Charge was funded by the authors.

This is an open access article distributed under the terms of the Creative Commons Attribution-NonCommercial-NoDerivatives License 4.0 (CC BY-NC-ND), which permits downloading and sharing the work provided it is properly cited. The work cannot be changed in any way or used commercially without permission from the journal. 


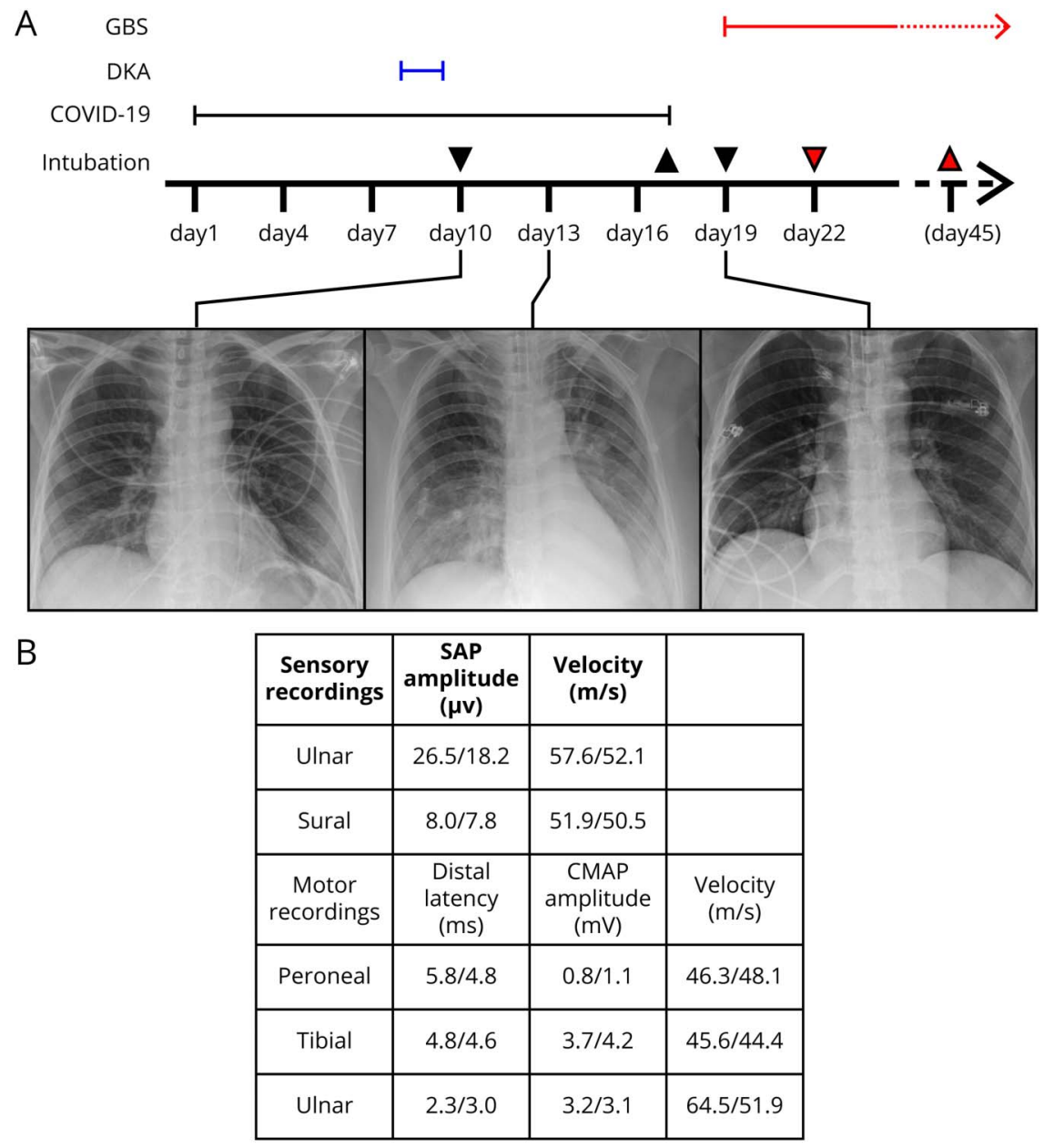

(A) Clinical course of our patient. Downward arrows indicate intubation, upward arrow indicates extubation, colored arrows indicate tracheostomy and decannulation. Chest x-ray images refer to the respective dates. (B) Data from nerve conduction studies on day 20 . *Abnormal. Reference for CMAP is $>5 \mathrm{mV}$ in all examined nerves. EMG was not performed. COVID-19 = coronavirus disease 2019; CMAP = compound muscle action potential; DKA = diabetic ketoacidosis; GBS = Guillain-Barré syndrome; SAP = sensory action potential.

potentials (figure, B). Antibodies against Gd1B were positive, whereas antibodies against other gangliosides were negative.

Laboratory analysis revealed selective immunoglobulin A deficiency ( $\operatorname{sgAD}$; serum IgA $<0.05 \mathrm{~g} / \mathrm{L}$ ) but was otherwise unremarkable for autoimmune or hematologic disorders. Virologic and serologic testing was negative for hepatitis, HIV, herpes viruses, other respiratory viruses, and Campylobacter.

We performed 5 courses of plasma exchange. After this, we observed early recovery with increasing muscle strength and reemerging muscle reflexes. However, bulbar palsy persisted and prompted early tracheostomy on day 22. Decannulation was performed on day 45 . Currently, symptoms mostly resolved but mild neurogenic dysphagia persists. C-peptide levels remain below thresholds, and insulin treatment is continued.

\section{Discussion}

We believe that our patient suffered from sIgAD since childhood but remained undiagnosed in the absence of symptoms until autoimmunity was finally induced by COVID-19.
SARS-CoV-2 has been identified as a potential trigger for GBS because its spike viral protein interacts with ganglioside antigens on human cells and thereby paves the way for an antiganglioside immune reaction. ${ }^{1}$ Such association has not been shown yet for T1D, but previous reports on the development of DKA within already 1 week after nivolumab treatment ${ }^{2}$ indicate that a single trigger can result in rapid-onset T1D in susceptible patients and normal $\mathrm{HbAlc}$ levels render preexisting yet undiscovered T1D unlikely here. In addition, sIgAD is a known risk factor for T1D. ${ }^{3}$

Moreover, previous cases on GBS after COVID-19 mostly showed an onset within 5-10 days supporting that COVID19 is a sufficient trigger of rapid-onset autoimmunity. ${ }^{1}$ However in GBS, the role of sIgAD is less clear, although asymptomatic ganglioside antibodies are more common in patients with sIgAD compared with the general population. ${ }^{4}$

Clinically, our case here shares many features with previously published reports. Our patients suffered from a predominantly axonal variant of GBS, which has been observed 
before. Previous patients also developed GBS already within 7-10 days after the onset of COVID-19. ${ }^{1}$ Furthermore, bulbar involvement has been described in previous cases. ${ }^{5,6}$ Especially, it was present in a case of Miller-Fisher syndrome that also presented with Gd1b antibodies. ${ }^{5}$ We have not observed ophthalmoplegia, yet dysphagia subsequent to bulbar palsy resulted in necessity for tracheostomy in our patient as described before. ${ }^{7}$

Finally, our findings expand the spectrum of autoimmunity after COVID-19. Although COVID-19 was repeatedly demonstrated as an inducer of GBS alone, we believe that the preexisting sIgAD significantly contributed to the development of 2 different autoimmune disorders after COVID-19.

\section{Study funding}

No targeted funding reported.

\section{Disclosure}

S. Pfeuffer received travel reimbursements from Sanofi Genzyme and Merck Serono; honoraria for lecturing from Sanofi Genzyme, Biogen, and Mylan Healthcare; and research support from Merck Serono, Diamed, and the German Multiple Sclerosis Society. M. Pawlowski and G.S. Joos declare no conflicts of interest. J. Minnerup received grants from EVER Pharma Jena GmbH and Ferrer International; travel grants from Boehringer Ingelheim; and speaking fees from Bayer Vital and Chugai Pharma. S.G. Meuth received honoraria for lecturing and travel expenses for attending meetings from Almirall, Amicus Therapeutics Germany, Bayer Health Care, Biogen, Celgene, Diamed, Genzyme, MedDay Pharmaceuticals, Merck Serono, Novartis, Novo Nordisk, ONO Pharma, Roche, Sanofi Aventis, Chugai Pharma, QuintilesIMS, and Teva. His research is funded by the German Ministry for Education and Research (BMBF), Deutsche Forschungsgemeinschaft (DFG), Else Kröner Fresenius Foundation, German Academic Exchange Service, Hertie Foundation, Interdisciplinary Center for Clinical Studies (IZKF) Muenster, German Foundation Neurology and Almirall, Amicus Therapeutics Germany, Biogen, Diamed, Fresenius Medical Care, Genzyme, Merck Serono, Novartis, ONO Pharma, Roche, and Teva. R. Dziewas declares no conflicts of interest. H. Wiendl received compensation for serving on Scientific Advisory Boards/Steering Committees for Bayer Healthcare, Biogen Idec, Sanofi Genzyme, Merck Serono, and Novartis; he has received speaker honoraria and travel support from Bayer Vital GmbH, Bayer Schering AG, Biogen, CSL Behring, EMD Serono, Fresenius Medical Care, Genzyme, Merck Serono, Omniamed, Novartis, and Sanofi
Aventis. He has received compensation as a consultant from Biogen Idec, Merck Serono, Novartis, Roche, and Sanofi Genzyme. Heinz Wiendl also received research support from Bayer Healthcare, Bayer Vital, Biogen Idec, Merck Serono, Novartis, Sanofi Genzyme, Sanofi US, and Teva. Go to Neurology.org/NN for full disclosures.

\section{Publication history}

Received by Neurology: Neuroimmunology \& Neuroinflammation May 8, 2020. Accepted in final form July 2, 2020.

\begin{tabular}{lll} 
Appendix & Authors & \\
\hline Name & Location & Contribution \\
\hline $\begin{array}{l}\text { Steffen } \\
\text { Pfeuffer, MD }\end{array}$ & $\begin{array}{l}\text { University } \\
\text { Hospital } \\
\text { Münster }\end{array}$ & $\begin{array}{l}\text { Study concept and design, acquisition } \\
\text { and interpretation of data, and } \\
\text { drafted the manuscript }\end{array}$ \\
\hline $\begin{array}{l}\text { Matthias } \\
\text { Pawlowski, } \\
\text { MD, PhD }\end{array}$ & $\begin{array}{l}\text { University } \\
\text { Hospital }\end{array}$ & $\begin{array}{l}\text { Acquisition and interpretation of data } \\
\text { and critical revision of the manuscript } \\
\text { for intellectual content }\end{array}$ \\
\hline Gunter Joos & $\begin{array}{l}\text { University } \\
\text { Hospital } \\
\text { Münster }\end{array}$ & $\begin{array}{l}\text { Acquisition of data and critical } \\
\text { revision of the manuscript for } \\
\text { intellectual content }\end{array}$ \\
\hline $\begin{array}{l}\text { Jens } \\
\text { Minnerup, MD }\end{array}$ & $\begin{array}{l}\text { University } \\
\text { Hospital } \\
\text { Münster }\end{array}$ & $\begin{array}{l}\text { Critical revision of the manuscript for } \\
\text { intellectual content }\end{array}$ \\
\hline $\begin{array}{l}\text { Sven G. Meuth, } \\
\text { MD, PhD }\end{array}$ & $\begin{array}{l}\text { University } \\
\text { Hospital } \\
\text { Münster }\end{array}$ & $\begin{array}{l}\text { Critical revision of the manuscript for } \\
\text { intellectual content }\end{array}$ \\
\hline $\begin{array}{l}\text { Rainer } \\
\text { Dziewas, MD }\end{array}$ & $\begin{array}{l}\text { University } \\
\text { Hospital } \\
\text { Münster }\end{array}$ & $\begin{array}{l}\text { Study concept and design and critical } \\
\text { revision of the manuscript for } \\
\text { intellectual content }\end{array}$ \\
\hline $\begin{array}{l}\text { University } \\
\text { Hospital }\end{array}$ & $\begin{array}{l}\text { Study concept and design and critical } \\
\text { revision of manuscript for intellectual } \\
\text { content }\end{array}$ \\
\hline
\end{tabular}

\section{References}

1. Dalakas MC. Guillain-Barre syndrome: the first documented COVID-19-triggered autoimmune neurologic disease: more to come with myositis in the offing. Neurol Neuroimmunol Neuroinflamm 2020;7:e781.

2. Lee S, Morgan A, Shah S, Ebeling PR. Rapid-onset diabetic ketoacidosis secondary to nivolumab therapy. Endocrinol Diabetes Metab Case Rep 2018;2018:18-0021.

3. Wang N, Shen N, Vyse TJ, et al. Selective IgA deficiency in autoimmune diseases. Mol Med 2011;17:1383-1396.

4. Barka N, Shen GQ, Shoenfeld Y, et al. Multireactive pattern of serum autoantibodies in asymptomatic individuals with immunoglobulin A deficiency. Clin Diagn Lab Immunol 1995;2:469-472.

5. Costello F, Dalakas MC. Cranial neuropathies and COVID-19: neurotropism and autoimmunity. Neurology Epub 2020 Jun 2.

6. Gutierrez-Ortiz C, Mendez A, Rodrigo-Rey S, et al. Miller Fisher Syndrome and polyneuritis cranialis in COVID-19. Neurology Epub 2020 Apr 17.

7. Schroder JB, Marian T, Muhle P, et al. Intubation, tracheostomy, and decannulation in patients with Guillain-Barre-syndrome-does dysphagia matter? Muscle Nerve 2019; 59:194-200. 


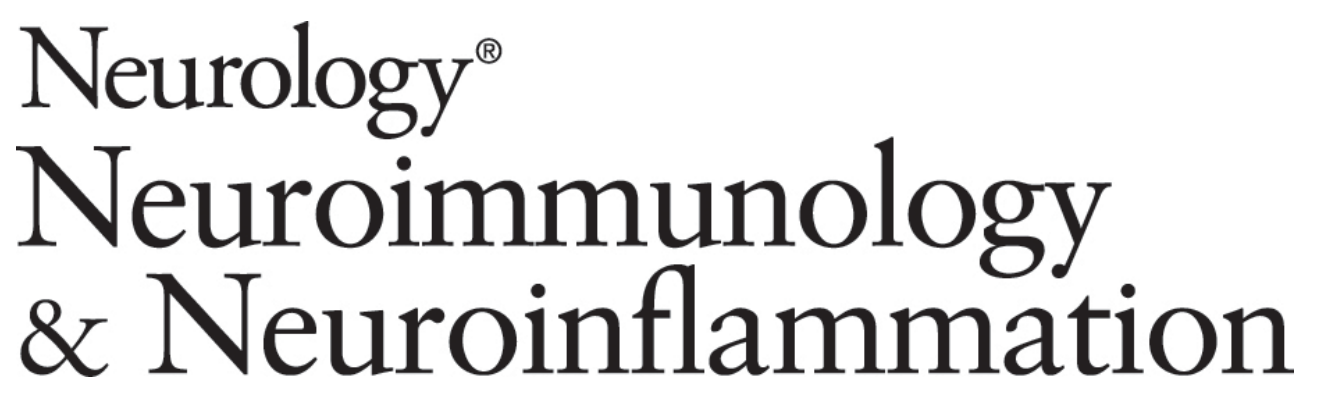

\author{
Autoimmunity complicating SARS-CoV-2 infection in selective IgA-deficiency \\ Steffen Pfeuffer, Matthias Pawlowski, Gunther S. Joos, et al. \\ Neurol Neuroimmunol Neuroinflamm 2020;7; \\ DOI 10.1212/NXI.0000000000000881
}

This information is current as of August 12, 2020

Neurol Neuroimmunol Neuroinflamm is an official journal of the American Academy of Neurology.

Published since April 2014, it is an open-access, online-only, continuous publication journal. Copyright

Copyright $\odot 2020$ The Author(s). Published by Wolters Kluwer Health, Inc. on behalf of the American

Academy of Neurology.. All rights reserved. Online ISSN: 2332-7812.

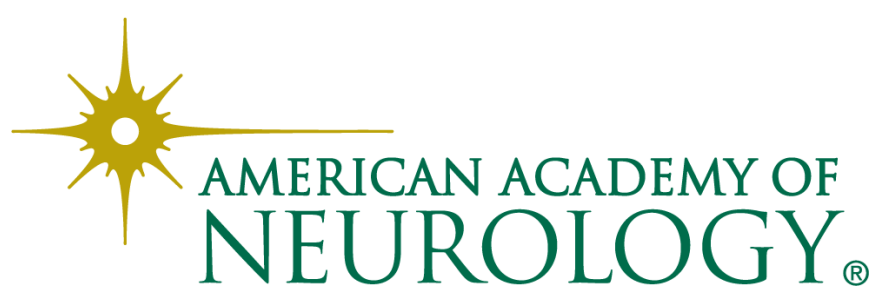




\section{Updated Information \& Services}

References

Citations

Subspecialty Collections

Permissions \& Licensing

Reprints including high resolution figures, can be found at: http://nn.neurology.org/content/7/6/e881.full.html

This article cites 5 articles, 1 of which you can access for free at: http://nn.neurology.org/content/7/6/e881.full.html\#\#ref-list-1

This article has been cited by 2 HighWire-hosted articles: http://nn.neurology.org/content/7/6/e881.full.html\#\#otherarticles

This article, along with others on similar topics, appears in the following collection(s):

All Immunology

http://nn.neurology.org//cgi/collection/all_immunology COVID-19

http://nn.neurology.org//cgi/collection/covid_19

Critical care

http://nn.neurology.org//cgi/collection/critical_care

Endocrine

http://nn.neurology.org//cgi/collection/endocrine

Guillain-Barre syndrome

http://nn.neurology.org//cgi/collection/guillainbarre_syndrome

Information about reproducing this article in parts (figures,tables) or in its entirety can be found online at:

http://nn.neurology.org/misc/about.xhtml\#permissions

Information about ordering reprints can be found online:

http://nn.neurology.org/misc/addir.xhtml\#reprintsus

Neurol Neuroimmunol Neuroinflamm is an official journal of the American Academy of Neurology.

Published since April 2014, it is an open-access, online-only, continuous publication journal. Copyright

Copyright $\odot 2020$ The Author(s). Published by Wolters Kluwer Health, Inc. on behalf of the American Academy of Neurology.. All rights reserved. Online ISSN: 2332-7812.

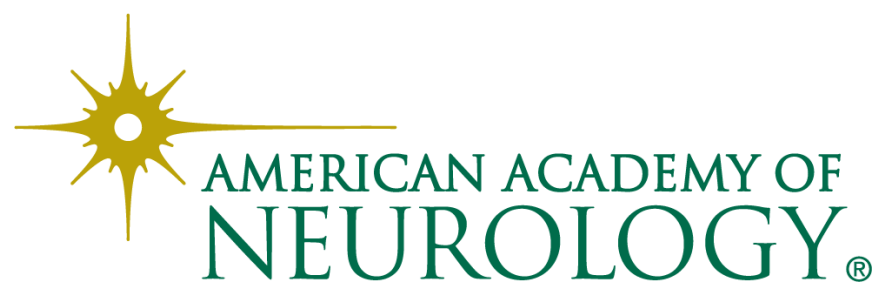

